\title{
Interdependence between Institutional Ownership and Leverage of Free Cash Flow: The Development of Agency Theory Model in Balancing Conflict of Interest in Indonesian Company
}

\author{
Christian Herdinata \\ International Business Management Program, School of Business, Universitas Ciputra, Indonesia \\ christian.herdinata@ciputra.ac.id
}

\section{Doi:10.5901/mjss.2015.v6n3p484}

\section{Abstract}

Agency conflict arises due to the differences of interest between owner, manager and creditors. Therefore, the researchers are trying to find the appropriate model in order to reduce the agency conflict issues that occur. The uncommon thing which became the originality and the recency of this study is to consider the interdependence relationship of institutional ownership variables and leverage to assess the appropriate control of the agency conflict that occurs by considering the real situation and circumstances faced by the company when the investment opportunities is high and low as well as high and low company risk. This study uses data of listed companies in Indonesia Stock Exchange (IDX) with the data for 12 years. The analysis technique used is simultaneous equations with GMM estimation techniques (Generalize Method of Moment). This research provides practical implications for owners, managers, creditors, investors, and capital market regulation in considering decisions related to the mechanism controlling agency conflicts through institutional ownership, leverage on free cash flow faced by companies in Indonesia, so that they can make decisions and provide useful strategic considerations useful for the companies, government regulation, banks (lenders), and society.

Keywords: Agency Conflicts, Institutional Ownership, Leverage, and Free Cash Flow

\section{Introduction}

Most of listed companies in Indonesia have institutional shareholders in the form of business which is often as a representation of the company's founder. This ownership is called Institutional Ownership. So institutional ownership will oversee and binded the management to act in according to the interests of shareholders (Mahadwartha, 2004). Therefore, it is important to be able to assess in terms of institutional ownership in Indonesia. In the other hand, to control the agency conflict can be done through leverage by "invite" third parties (creditors or debtholders, hereinafter referred to as the creditor) to participate in supervising the management and operational of the company generaly. Leverage bind the management through their obligation to repay the debt. This binding reduces the ability of management to conduct the use of free cash flow for personal interest (perquisites) for example: luxury office space, business travel exceeds the standard positions, provision of facilities that do not comply with the requirement, and others that do not add value to the operating companies (Cohen and Cyert, 1965: 355). At the time of the shareholders to supervise the use of leverage, it is expected to reduce the utilization of free cash flow by the management. Therefore, further research is needed to examine leverage in order to reducing agency conflict. The main objective of this study is to prove that institutional ownership and debt policy can be used as a control mechanism against free cash flow in Indonesian company so that it can reduce conflict caused by inappropriate free cash flow.

Based on this explanantion, institutional ownership variable, leverage, and free cash flow need to be observed in an attempt to do mechanism controlling of the agency conflict that occurred in companies in Indonesia. The unique thing of this study is to consider the situation and circumstances faced by the company as investment opportunities that can affect relationships of interdependence that occur between institutional ownership and leverage on free cash flow. The study which has been done before has not examined the interdependency relationships that occur between institutional ownership and leverage by oberserving the situation and condition of the company. Therefore, this study examines the interdependence relationship between institutional ownership, leverage and free cash flow, as well as considering theoretical framework which is made in reference to situation and conditions ofhigh and low investment opportunities as well by using the relevant control variables and using simultaneous equations to get better analysis results. 


\section{Literature Review}

\subsection{Institutional Ownership}

Pozen (1994) argues that institutional ownership will act to support shareholders if the suppression which is done have economic value or directly affect the stock price. Listed companies in Indonesia have different structures composition. Most of the listed companies have shareholders in the form of business entities which is often as a representation of the company founder. This study called the institutional ownership as internal institutional ownership. Stocks exchange which are sold on public shareholders also owned by institutional investors. Institutional ownership in punblic stock is called institutional ownership external. Ismiyanti (2003) found that the average of internal institutional ownership in the period 1997-2001 reach $66 \%$ of the total shares outstanding. This shows that $34 \%$ spread to public investors (individuals), management, commissioners, and external institutional ownership. This is different than in the United States, the external institutional ownership reached $52.36 \%$ of the total shares outstanding (Chen and Steiner, 1999).

Jensen and Meckling (1976)stated that institutional ownership has a very important role in minimizing agency conflicts that occur between managers and shareholders. The existency of institutional investors are considered capable of being an effective monitoring mechanism in any decision made by the manager. This is due to the institutional investors involved in strategic decision-making is not easy to believe the earnings manipulation. According Tarjo (2008) institutional ownership is ownership of shares owned by institutions or institutions such as insurance companies, banks, investment companies and other institutional ownership. Institutional Ownership has significance part in monitoring management because of the presence of institutional ownership leads to more optimal control. Monitoring will ensure prosperity for the shareholders. The influence of institutional ownership as a supervisor agent showed through their big investment in the capital market. High levels of institutional ownership will lead to greater oversight efforts by institutional investors so as to preclude opportunistic behavior of managers. Wien (2010) states that institutional ownership has advantages such as: (1) Has professionalism in analyzing information in order to test the reliability of information.( 2) Have a strong motivation to implement tighter controls over the activities occurring within the company.

\subsection{Free Cash Flow}

Jensen (1986) defines free cash flow is the remainder of the funding the entire project which resulted in net present value (NPV) positvie which discounted at the rate of relevant capital costs. This free cash flows that often become the trigger of divergence of interests between shareholders and manager. When the free cash flow available, manager allegedly going to waste the free cash flow and caused inefficiencies in the company or will invest the free cash flow with small return (Smith and Kim, 1994). White et al (2003) defines free cash flow as available discretionary to the company. Free cash flow can be used for discretionary uses such as acquisitions, capital expenditure to the orientation of growth (growthoriented), debt payments, and payments to shareholders in the form of dividends. Ross et al (2000) defines free cash flow as corporate cash that can be distributed to creditors or shareholders who are not used to working capital (working capital) or investment in fixed assets. For companies that do capital expenditures, free cash flow will reflect clearly which company that still has the ability in the future and which are not. Free cash flow is said to have content of information when free cash flow gives signals to shareholders (Rosdini, 2009).

Penman (2001) defines "free cash flow as cash from operating earnings after withholding some of the profits as assets and a net cash generated from operations that demonstrate the company's ability to pay claims for debt and equity". Substantial free cash flow will lead to incorrect behavior of managers and bad decisions which are not for the shareholders interest. In other words, managers have a tendency to use excess profits to consumption and opportunistic behavior because they receive the full benefits from such activities, but are less willing to bear the risk of costs incurred. This leads to the hypothesis control to create and increase the debt (Jensen, 1986). How to resolve the alleged use of free cash flow by manager as described earlier, Jensen (1986) suggested the need for the establishment of a debt is called "control hypothesis". Thus, shareholders of the company will have increased control over their management team. For example, if the company issued new debt and use the result to attract outstanding shares or pay dividends, management is required to expend cash to pay interest and principal on the debt which simultaneously reducing the amount of free cash flow (Isrina, 2006). Jensen (1986) argue that contrary to the pecking order theory hypothesis is managers have an incentive to finance investment from internal capital with the intention of increasing the resources that can be controlled by them. This effort is intended to reduce the supervision of the capital markets that occurred when the company had to increase the debt capital (Easterbrook , 1984). 


\subsection{Leverage}

Leverage is an alternative way to relocate supervision cost by the owner to the creditor, the use of debt also encourages managers to act more disciplined to avoid bankruptcy (Harris and Raviv, 1990 and Megginson, 1997: 335). Research Maloney, McCormick and Mitchell (1993) find that debt improve management in making decision. These findings support the statement that debt is surveillance or monitoring (monitoring) to control the agency conflict. Nevertheless on the other hand the growth debt cause the debt agency conflict since there will be more interest from other parties to the company. The more interest, the more difficult to align the interests of each party then agency conflict increases. Friend and Lang (1988) also found that leverage is used to reduce the agency conflict by inviting external parties to participate in conducting surveillance to the management.

Bhatala, Moon and Rao (1994) found that there is a substitution effect between institutional ownership with the external leverage in controlling agency conflict and showed that ownership structure affects the agency conflict. Bhatala, Moon and Rao (1994) in this case also tested the balancing of agency theory (or often called a trade-off models of agency cost) that there are agency costs when using the control method of agency conflicts through debt or dividends so that the company concerned that lower agency costs . The action taken by the company is making exchange (trade-off) between leverage and dividend for lower agency costs. The linkage between leverage, dividend, managerial ownership and institutional ownership discussed by Crutchley, Jensen, Jahera and Raymond (1999), who found that the balancing of agency theory supported in the relationship of interdependency leverage and dividend policy, leverage interdependency to managerial ownership, and relationship interdependency of managerial ownership to institutional ownership, but is not supported for the relationship of leverage interdependency to institutional ownership.

\section{Hypothesis Formulation}

\subsection{The influence of institutional ownership on free cash flow}

At the time company has high investment opportunities status, the higher investment opportunities the company has. In these conditions the company requires more funds from free cash flow to invest since of high investment opportunities. On the other hand, at the time company has low investment opportunities status, the company has a low investment opportunities. In these conditions small company requires funds from free cash flow to invest because of the low investment opportunities. Institutional shareholders will use free cash flow for investmen when the investment opportunities high. On the contrary, when the investment opportunity is low the institutional shareholders will not use free cash flow. Therefore, when the investment opportunity is high, free cash flow is relatively small, whereas at the investment opportunity is low, free cash flow is relatively large. Therefore, the hypothesis formed as follows:

$\mathrm{H}_{1 \mathrm{a}}$ : Institutional Ownership has negative effect on free cash flow at the time when the investment opportunities status is low $\mathrm{H}_{1 b}$ : Institutional Ownership has positive effect on free cash flow at the time when investment opportunities status is high

\subsection{The influence of leverage on free cash flow}

At time when the company has high investment opportunities status, the company has high investment opportunities. In these conditions the company requires substantial funds from free cash flow to invest because of the high investment opportunities. On the other hand it requires high increase of the debt to be able to control the high free cash flow that can be done by the creditors because of high risk level to ensure that the investments have performed optimally. At the time when the company has low investment opportunities status, the company has low investment opportunities. In this condition the company only needs small fund of free cash flow to invest because of the low investment opportunities. Therefore, controlling through leverage is needed at the time of low investment opportunities than at the time of high investment opportunities due larger free cash flow. Therefore, leverage can be used as a control for free cash flow. Therefore, the hypothesis is formed as follows:

$\mathrm{H}_{2 a}$ : leverage negatively affects free cash flow at the time of high investment opportunities status

$\mathrm{H}_{2 b}$ : leverage negatively affect free cash flow at the time of low investment opportunities status 


\subsection{Interdependence relationship of leverage and institutional ownership}

Institutional ownership represents the power source that will lead to omptimal monitoring increasement to the company performance. This means that the greater the percentage of shares owned by institutional investors will lead monitoring efforts more effective because it can control the opportunistic behavior by managers. This monitoring activity will reduce agency costs because it allows the company to use lower levels of debt (Isrina, 2006). According to Crutchley et al (1999), the effect of leverage on institutional ownership is positive. High leverage caused the company monitored by the debtholder lead managers to act in accordance with the debtholders and shareholders interest, so that this condition w attract the entry of institutional ownership. The study results by Wahidahwati (2002) showed that the presence of institutional ownership in the manufacturing industry have a significant effect on corporate leverage. This is consistent with Moh'd et al (1998) that institutional investors in the manufacturing industry aware that their presences can monitor the company manager behavior effectively. At the time of high investment opportunities, free cash flow relatively become smaller. Therefore, the control can be done through institutional ownership or leverage, while at the time of low investment opportunities, free cash flow relatively become larger. Therefore, the control can be done altogether through institutional ownership and leverage. Therefore, the hypothesis is formed as follows:

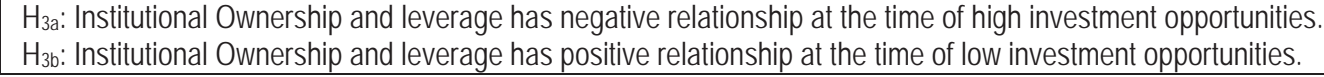

\section{Conceptual Framework of Research}

Based on a literature review and formulation of hypotheses, the models in the study of interdependence relationship between institutional ownership and debt policy to free cash flow, as follows:

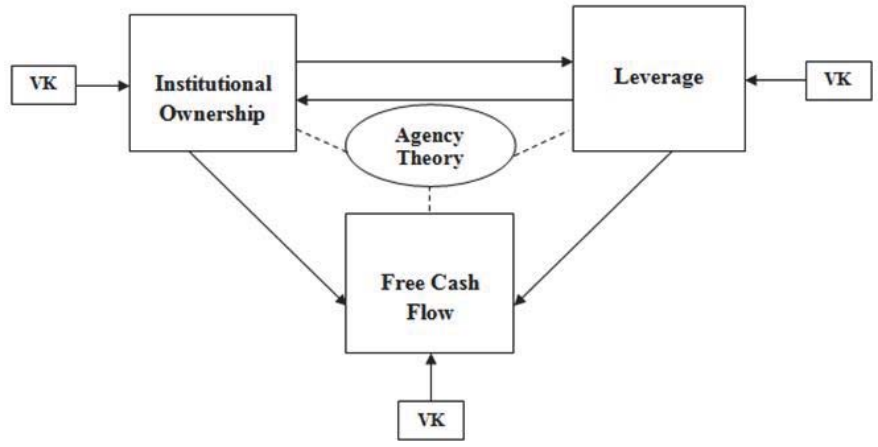

Description:

VK: Research control variables that affect the institutional ownershipleverage, and free cash flow. : The relationship described explicitly.

------: The relationship described implicitly.

Figure 1. Research Framework Concept

\section{Research Methods}

The data used in this study consists of stock market data and financial statement data of manufacturing companies in Indonesia from 2001 to 2012 at the Indonesia Stock Exchange (IDX). The study sample consist of companies in Indonesia that provides stock market data information and complete financial statements for all periods of analysis. Separation of high investment opportunities samples and low investment opportunities is by using book to market value of assets as a proxy of investment opportunities. The following are some of the main variables, namely: (1) Institutional Ownership; Institutional ownership which is used is the internal institutional ownership which owned by a legal entity that listed as a non-public shareholder. This information can be known through financial statements listed in the Indonesia Stock Exchange (IDX) and cross-checked with the data Indonesian Capital Market Directory (ICMD) . Internal institutional ownership is symbolized INST. The formula used to calculate the internal institutional ownership (INST) proportionas is as follows: INST = Internal Institutional Ownership Percentage; (2) Leverage; Debt Policies (leverage) symbolized as LEV. Debt interest burden proxy from total debt minus accounts payable and tax debts. The use of debt interest burden refers to the study of Baskin (1989) that debt without interest burden such as debt for trade is not capital source. The formula used to describe the leverage (LEV) as follows: LEV = (Debt interest burden) $t /$ (Total Fixed Assets) $t$; (3) Free 
Cash Flow; Free cash flows use Ross et al (2000) calculation. Free cash flow is symbolized in FCF. The formula used to calculate free cash flow (FCF) as follows: FCF = OCF-Tax-lexp-Cdiv-Pdiv. This study uses simultaneous equations with GMM estimation techniques (Generalize Method of Moment) to test the research hypothesis. Simultaneous equations used in this study because the variables of institutional ownership and leverage in an analytical model are the interdependent endogenous variables (Greene, 2000).

The research method with GMM estimation technique (Generalize Method of Moment) used in this study since GMM estimation technique (Generalize Method of Moment) can reduce the impact of heteroscedasticity and GMM (Generalize Method of Moment) has been able to reduce the high residual correlation between the equations in this study.

\section{Data Analysis Results}

Here are the results of data analysis showed the influence of institutional ownership and leverage on free cash flow. In this research also uses the control variable that is operating cash flow, public ownership, risk roa, managerial ownership, return on assets, risk roa, asset structure, growth assets, interest bearing debt by considering group of companies condition which is high investment opportunities and low investment opportunities.

Table 1. Analysis Regression Result of Generalized Method of Moment (GMM) Group of Companies with High Investment Opportunities

Panel A - Depeneden Variable: Free Cash Flow (FCF)

\begin{tabular}{ccccc}
\hline \hline Variable & Coefficient & Std. Error & t-Statistic & Prob. \\
\hline \hline INTERCEPT & -0.045925 & 0.171049 & -0.268488 & 0.7883 \\
INST_OWN & -0.075915 & 0.265298 & -0.286152 & 0.7748 \\
LEVERAGE & 0.190904 & 0.072829 & 2.621274 & $0.0088^{\star * *}$ \\
OCF & 0.962877 & 0.245045 & 3.929382 & $0.0001^{\star \star *}$ \\
RISK_ROI & -0.158753 & 0.068325 & -2.323509 & $0.0202^{\star *}$ \\
MGR_OWN & 13.11899 & 6.630383 & 1.978617 & $0.0480^{\star *}$ \\
ROA & -0.041364 & 0.216391 & -0.191154 & 0.8484 \\
SA & -0.152505 & 0.054040 & -2.822088 & $0.0048^{\star \star *}$ \\
AGR_ST & 0.013826 & 0.004363 & 3.168596 & $0.0016^{\star * *}$ \\
\hline R $^{2} 0$
\end{tabular}

$\mathrm{R}^{2} 0.123713$

Adj R 0.114175

Panel B - Depeneden Variabel: Institutional Ownership (INST_OWN)

\begin{tabular}{ccccc}
\hline \hline Variable & Coefficient & Std. Error & t-Statistic & Prob. \\
\hline \hline INTERCEPT & 0.881826 & 0.012954 & 68.07137 & 0.0000 \\
LEVERAGE & -0.000111 & 0.004894 & -0.022764 & 0.9818 \\
PUB_OWN & -0.837066 & 0.029181 & -28.68549 & $0.0000^{\star * *}$ \\
OCF & 0.043731 & 0.027077 & 1.615090 & $0.1064^{\star}$ \\
RISK_ROI & -0.010543 & 0.004632 & -2.276076 & $0.0229^{\star *}$ \\
ROA & 0.002254 & 0.005094 & 0.442411 & 0.6582 \\
SA & 0.008445 & 0.003705 & 2.279483 & $0.0227^{\star *}$ \\
\hline
\end{tabular}

$R^{2} 0.513599$

Adj $R^{2} 0.509640$

Panel C - Depeneden Variabel: Leverage (LEVERAGE)

\begin{tabular}{|c|c|c|c|c|}
\hline Variable & Coefficient & Std. Error & t-Statistic & Prob. \\
\hline INTERCEPT & 0.307980 & 0.089092 & 3.456888 & 0.0006 \\
\hline INST_OWN & -0.318020 & 0.118360 & -2.686886 & $0.0073^{\star \star *}$ \\
\hline OCF & -0.847901 & 0.280275 & -3.025243 & $0.0025^{\star \star \star}$ \\
\hline RISK_ROI & 0.898505 & 0.017795 & 50.49073 & $0.0000^{* * *}$ \\
\hline MGR_OWN & -7.324582 & 2.724459 & -2.688454 & $0.0072^{\star * *}$ \\
\hline $\mathrm{ROA}$ & 0.046921 & 0.127735 & 0.367329 & 0.7134 \\
\hline SA & 0.751973 & 0.025083 & 29.97899 & $0.0000^{* * *}$ \\
\hline AGR_ST & -0.063428 & 0.003478 & -18.23632 & $0.0000^{\star * \star}$ \\
\hline & & & & \\
\hline
\end{tabular}

Description: ${ }^{* \star *},{ }^{* \star},{ }^{*}$ significant at probability level of 0:01, 0:05, and 0.1

Sources: Data Processed 
Based on Table 1 shows that the group of companies of high investment opportunities show that higher institutional ownership, the lower free cash flow, but the higher the leverage, the higher the free cash flow. The influence of institutional ownership on free cash flow at group companies of high investment opportunities is negative at 0.7748 while the leverage effect on free cash flow is positive and significant at 0.0088 . This shows that the hypothesis $\left(\mathrm{H}_{1 a}\right)$ and hypotheses $\left(\mathrm{H}_{2 \mathrm{a}}\right)$ is accepted. On the other side, the interdependence relationship between institutional ownership and leverage on group companies of high investment opportunities is negative. It is shown from the relationship between leverage towards institutional ownership is negative and the effect of institutional ownership on the leverage is negative. This shows that the hypothesis $\left(\mathrm{H}_{3}\right)$ accepted.

Table 2. Results of Generalized Method of Moment (GMM) Regression Analysis Group of Companies of Low Investment Opportunities Low

Panel A - Dependent Variable: Free Cash Flow (FCF)

\begin{tabular}{ccccc}
\hline \hline Variable & Coefficient & Std. Error & t-Statistic & Prob. \\
\hline \hline INTERCEPT & -0.313036 & 0.112139 & -2.791508 & 0.0053 \\
INST_OWN & 0.159235 & 0.144739 & 1.100156 & 0.2714 \\
LEVERAGE & 0.091300 & 0.046952 & 1.944556 & $0.0520^{\star \star}$ \\
OCF & 1.621644 & 0.329829 & 4.916623 & $0.0000^{\star \star \star}$ \\
RISK_ROI & -0.108932 & 0.082336 & -1.323026 & $0.1860^{\star}$ \\
MGR_OWN & 3.368446 & 1.260018 & 2.673331 & $0.0076^{\star \star \star}$ \\
ROA & 0.457819 & 0.425334 & 1.076376 & 0.2819 \\
SA & 0.037117 & 0.048768 & 0.761103 & 0.4467 \\
AGR_ST & 0.007633 & 0.006642 & 1.149235 & 0.2506 \\
\hline
\end{tabular}

$\mathrm{R}^{2} 0.088537$

Adj R2 0.078616

Panel B - Dependen Variabel: Institutional Ownership (INST_OWN)

\begin{tabular}{|c|c|c|c|c|}
\hline Variable & Coefficient & Std. Error & t-Statistic & Prob. \\
\hline INTERCEPT & 0.870100 & 0.020147 & 43.18732 & 0.0000 \\
\hline LEVERAGE & 0.023712 & 0.010997 & 2.156341 & $0.0312^{* *}$ \\
\hline PUB_OWN & -0.844527 & 0.030186 & -27.97775 & $0.0000 * * *$ \\
\hline$\overline{\mathrm{OCF}}$ & -0.127730 & 0.047464 & -2.691076 & $0.0072^{\star \star *}$ \\
\hline RISK_ROI & 0.016324 & 0.006501 & 2.510859 & 0.0121 *** \\
\hline $\mathrm{RO} \bar{A}$ & 0.073075 & 0.091097 & 0.802163 & 0.4225 \\
\hline SA & -0.001185 & 0.014655 & -0.080848 & 0.9356 \\
\hline Variable & Coefficient & Std. Error & t-Statistic & Prob. \\
\hline IINTERCEPT & 0.451089 & 0.056506 & 7.983083 & 0.0000 \\
\hline INST_OWN & 0.199067 & 0.074669 & 2.665979 & $0.0077^{\star * *}$ \\
\hline$\overline{O C F}$ & 0.519090 & 0.236932 & 2.190878 & $0.0286 * *$ \\
\hline RISK_ROI & -0.063324 & 0.039335 & -1.609886 & $0.1076^{*}$ \\
\hline MGR_OWN & -5.130900 & 1.245256 & -4.120357 & $0.0000 * * *$ \\
\hline $\mathrm{ROA}$ & -0.579461 & 0.273659 & -2.117452 & $0.0343^{\star *}$ \\
\hline SA & 0.104969 & 0.046178 & 2.273142 & $0.0231^{\star *}$ \\
\hline AGR_ST & -0.013721 & 0.012721 & -1.078559 & 0.2809 \\
\hline R2 & 0.025160 & & & \\
\hline Adj R2 & 0.015889 & & & \\
\hline
\end{tabular}

Description: ${ }^{* * *},{ }^{* *},{ }^{*}$ significant at a probability level of 0:01, 0:05, and 0.1

\section{Sources: Data Processed}

Based on Table 2 shows that the group companies of low investment opportunities show that higher institutional ownership the higher free cash flow but the higher leverage, the higher free cash flow. The influence of institutional ownership on free cash flow in group companies of low investment opportunities is positive at 0.2714 , while the effect of leverage on free cash flow is positive and significant at 0.0520 . This shows that the hypothesis $\left(\mathrm{H}_{1 b}\right)$ and hypothesis $\left(\mathrm{H}_{2 b}\right)$ is accepted. On the other side, the interdependence relationship between institutional ownership and leverage in the low 
investment company group is positive and significant. It is shown from the relationship between leverage towards institutional ownership is positive and significant at 0.0312 whereas the effect of institutional ownership on the leverage is positive and significant at 0.0077 . This shows that the hypothesis $\left(\mathrm{H}_{3 b}\right)$ is accepted.

\section{Discussion}

The influence of institutional ownership on free cash flow to high investment opportunities company group is negative. It shows that institutional shareholders are taking advantage of the free cash flow for investment. Therefore, the higher the institutional ownership, the lower free cash flow because it has been used for investment. This is related to institutional ownership which have major stake in the company so that institutional shareholders are trying to maximize the profits by using free cash flow. The influence of leverage and free cash flow on the high investment opportunities company group is positive. This shows that the debt is used as a control to free cash flow, it means that the higher the debt, the higher the free cash flow due to the high investment opportunities, free cash flow is used for investment so that control mechanisms is needed through leverage. Therefore, the use of free cash flow for investment in high investment opportunities will be controlled through debt policy. Interdependency relationship between institutional ownership on leverage to the high investment opportunities is negative but not significant. It shows that the relationship between institutional ownership and leverage is tend to lead into substitution relationship but not significant, it means to perform the control mechanism on free cash flow can be done through institutional ownership or leverage due to at the time of high investment opportunities shows free cash flow which is relatively small.

The influence of institutional ownership on free cash flowto the low investment opportunities company group is positive. It shows that institutional shareholders lack in taking advantage of the free cash flow for investment because of the low investment opportunities. Therefore, the higher the institutional ownership, the higher free cash flow due to low investment opportunities. The influence of levereage to free cash flow on low investment opportunities company group is positive. It shows that the debt is used as a control to free cash flow, it means the higher the debt, the higher free cash flow due to low investment opportunities since free cash flow is rarely used for investment so that control mechanisms through leverage is needed. Therefore, free cash flow that not used to invest in low investment opportunities will be controlled through leverage. Interdependency relationship between institutional ownership on leverage to the low investment opportunities company grop is positive and significant. It shows that the relationship between institutional ownership and leverage is a complementary relationship, it means to perform the control mechanism of the free cash flow is done altogether through institutional ownership and leverage because at the time of low investment opportunity showed that free cash flow is relatively large.

\section{Conclusions and Recommendations}

At the time of high investment opportunities, free cash flow is relatively small because it is used to invest so that the higher institutional ownership, the lower free cash flow. At the time of low investment opportunities, free cash flow is relatively large because it is not used for investment, the higher institutional ownership, the higher the free cash flow. At the time of high investment opportunities and low debt to monitor the usage of free cash flow as a control mechanism through the creditors. At the time of high investment opportunities high then the pattern of interdependency relationship between institutional ownership and leverage is negative, but at the time of low investment opportunities, the pattern of interdependency relationship between institutional ownership and leverage is positive or complementary. Here are some suggestions from this study : (1) For company owner, they may consider control mechanism on free cash flow through institutional ownership and leverage; (2) For creditors or the banks may consider the results of this study related to the company policy on leverage so that creditors can optimize to provide credit to the company; (3) Suggestions for the next research is to consider the performance of the company as a variable in the testing model so it able to show the effect of the control mechanisms do on free cash flow. In addition, consider testing as inter-variable non-linear.

\section{References}

Baskin, J. (1989). An Empirical Investigation of the Pecking Order Hypothesis, Financial Management, Spring, 26-35.

Bathala, C.T., et al., (1994). Managerial Ownership, Debt Policy and The Impact of Institutional Holdings: An Agency Perspective, Financial Management, 38-50.

Chen, C.R., \& Steiner, T.L. (1999). Managerial Ownership and Agency Conflicts: A Nonlinear Simultaneous Equation Analysis of Managerial Ownership, Risk Taking, Deb Policy and Dividend Policy, The Financial Review 34, 119-136.

Cohen, K.J., \& Cyert, R.M. (1965). Theory of the Firm: Resource Allocation in a Market Economy, Prentice-Hall, Inc, Englewood Cliffs, New Jersey.

Crutchley, C.E., et al., (1999). Agency Problem and The Simultaneity of Financial Making: The Role of Institutional Ownership, 
International Review of Financial Analysis 8/2, 177-197.

Easterbrook, F.H. (1984). Two Agency-cost Explanation of Dividends, American Economic Review, 74, September, 650-659.

Friend, I. \& Lang, L.H.P. (1988). An Empirical Test of the Impact of Managerial Self-Interest on Corporate Capital Structure, Journal of Finance 43, 271282.

Greene, William H. (2000). Econometric Analysis, Fourth Edition, Prentice Hall Inc., Upper Saddle River New Jersey.

Harris, M., \& A. Raviv. (1990). Capital Structure and the Information Role of Debt, The Journal of Finance, June, 321-349.

Ismiyanti, F. (2003). Kepemilikan Manajerial, Kepemilikan Institusional, Risiko, Kebijakan Utang dan Kebijakan Dividen: Analisis Persamaan Simultan, Thesis tidak dipublikasikan, Pascasarjana Universitas Gadjah Mada.

Isrina, (2006). Analisis Pengaruh Free Cash Flow Dan Struktur Kepemilikan Saham Terhadap Kebijakan Utang Pada Perusahaan Manufaktur Di Indonesia, Skripsi, Universitas Islam Indonesia, Yogyakarta.

Jensen, M.C. (1986). Agency Cost of Aliran kas bebas, Corporate Finance and Takeovers, American Economic Review, 76, May, 323329.

Jensen, M.C., \& W. H. Meckling. (1976). Theory of the Firm: Managerial Behavior, Agency Cost, and Ownership Structure, Journal of Financial Economic, 3, October, 305-360.

Mahadwartha, P.A. (2004). Pengawasan dan Pengikatan Berbasis Kepemilikan Institusional Internal, Disertasi tidak dipublikasikan, Pascasarjana Universitas Gadjah Mada.

Maloney, M.T. et all., (1993). Managerial Decision Making and Capital Structure, Journal of Business 66, 189-217.

Megginson, W.L. (1997). Corporate Finance Theory, Addison-Wesley Educational Publishers Inc.

Moh'd., M. A., Perry, Rimbey. (1998). The Impact of Ownership Stucture on Corporate Debt Policy : A Time Series Cross Sectional Analysis, Financial Review, August, Vol. 33, pp. 85-99

Penman, S. H, 2001. Financial Statement Analysis and Securities Valuation, Edisi Kedua, Mc Graw-Hill, Inc.

Pozen, R.C. (1994). Institutional Investors: The Reluctant Activist, Harvard Business Review, 140-150.

Rosdini, Dini. 2009. Pengaruh Free Cash Flow Terhadap Dividen Payout Ratio. Bandung: Working Paper in Accounting and Finance, Universitas Padjajaran.

Ross, Stephen A. et al., (2000). Fundamentals of Corporate Finance.Fifth Edition. Boston: Irwin McGraw-Hill.

Smith, Richard L., and Joo-Hyun Kim, 1994, The combined effects of free cash $\mathrm{f}$ low and financial slack on bidder and target stock returns, Journal of Business 67, 281-310.

Tarjo. (2008). Pengaruh Konsentrasi Kepemilikan Institusiona dan Leverage Terhadap Manajemen Laba, Nilai Pemegang saham serta Cost of Equity Capital. Simposium Nasioanal Akuntansi XI. Pontianak.

Wahidawati. (2002). Pengaruh Kepemilikan Manajerial dan Kepemilikan Institusional pada Kebijakan Hutang Perusahaan: Sebuah Perspektif Theory Agency. Jurnal Riset Akuntansi Indonesia, Vol. 5, No. 1, 1-16 